\title{
Does agricultural cooperative membership help reduce the overuse of chemical fertilizers and pesticides? Evidence from rural China
}

Tongshan Liu ( $\square$ liutsh@njfu.edu.cn )

Nanjing Forestry University https://orcid.org/0000-0002-7843-9166

Gang Wu

Nanjing Forestry University

\section{Research Article}

Keywords: Agricultural cooperative, Fertilizers, Pesticides, Family farm, Endogeneity, China

Posted Date: April 14th, 2021

DOl: https://doi.org/10.21203/rs.3.rs-357150/v1

License: (c) (1) This work is licensed under a Creative Commons Attribution 4.0 International License. Read Full License

Version of Record: A version of this preprint was published at Environmental Science and Pollution Research on September 4th, 2021. See the published version at https://doi.org/10.1007/s11356-02116277-0. 
Does agricultural cooperative membership help reduce the overuse of chemical fertilizers and pesticides? Evidence from rural China

\author{
Tongshan Liu \\ College of Economics and Management, Nanjing Forestry University, No. 159 Longpan, \\ Nanjing, 210037, China \\ E-mail: liutsh@njfu.edu.cn \\ Telephone number: +8613717650008 \\ Gang $\mathrm{Wu}$ \\ College of Economics and Management, Nanjing Forestry University, No. 159 Longpan, \\ Nanjing, 210037, China \\ E-mail:wugang@njfu.edu.cn
}

\author{
Corresponding author \\ Professor Tongshan Liu \\ College of Economics and Management \\ Nanjing Forestry University \\ No. 159 Longpan \\ Nanjing, 210037 \\ China
}

\title{
Acknowledgements
}

The authors acknowledge the financial support from the National social science foundation of China (Project ID: 19BJY127).

\begin{abstract}
The overuse of chemical fertilizers and pesticides (CFPs) has negatively impacted the environment and human health. It is an urgent issue that should be addressed. In this study, we investigate whether agricultural cooperatives can serve as an institutional arrangement that helps reduce the consumption of CFPs, using the data of 2012 family farms from the Ministry of Agriculture and Rural Affairs of China. Various approaches, including instrumental variable based two-stage residual inclusion approach (2SRI), endogenous switching probit (ESP) model, and endogenous switching regression (ESR) model, are utilized to help address the endogeneity issues of the cooperative membership variable. The results show that agricultural cooperative membership significantly increases the probability of reducing fertilizers and pesticides of the family farms and improves net return per yuan CFPs. Our findings highlight the importance of promoting the development of agricultural cooperatives to support green agricultural production in China.
\end{abstract}

Keyword: Agricultural cooperative; Fertilizers; Pesticides; Family farm; Endogeneity; China 


\section{$47 \quad$ Abstract}

The overuse of chemical fertilizers and pesticides (CFPs) has negatively impacted the environment and human health. It is an urgent issue that should be addressed. In this study, we investigate whether agricultural cooperatives can serve as an institutional arrangement that helps reduce the consumption of CFPs, using the data of 2012 family farms from the Ministry of Agriculture and Rural Affairs of China. Various approaches, including instrumental variable based two-stage residual inclusion approach (2SRI), endogenous switching probit (ESP) model, and endogenous switching regression (ESR) model, are utilized to help address the endogeneity issues of the cooperative membership variable. The results show that agricultural cooperative membership significantly increases the probability of reducing fertilizers and pesticides of the family farms and improves net return per yuan CFPs. Our findings highlight the importance of promoting the development of agricultural cooperatives to support green agricultural production in China.

58 Keyword: Agricultural cooperative; Fertilizers; Pesticides; Family farm; Endogeneity; China

JEL Codes: D13; J54 


\section{Introduction}

The overuse of chemical fertilizers and pesticides (CFPs) needs immediate, practical solutions in China to ensure food safety and environmental sustainability. China had $8.57 \%$ of world farmland but consumed $24.97 \%$ fertilizers (by nutrients) and 43.03\% pesticides in 2018 (FAOSTAT). Low application efficacy is one reason contributing to the overuse of CFPs (Li et al. 2019; Wu et al. 2018; Zheng et al. 2019). Wu et al. (2018) reported that the average use efficacy of nitrogen fertilizer in wheat, rice, and maize production in China is $31 \%$, compared with 53-63\% in North America and Europe. Long-term overuse of CFPs causes food safety concerns and severe non-point pollution issues (Huang et al. 2018; Huang and Jiang 2019; Pan et al. 2020). Therefore, China has taken a series of measures to increase the CFPs utilization rate and reduce the quantity to promote sustainable agricultural production. The Chinese government also has issued a series of policies to regulate the application of the CFPs and develop green agrarian production.

About 200 million very small part-time farmers in China practice farming based on traditional experience but not modern agricultural technologies. The knowledge and resource constraint they face is the primary cause of the misuse or overuse of CFPs (Kuang et al. 2018; Zhou et al. 2016; Zhou and Jin 2009). As a prominent business institutional form in the world agri-food system, agricultural cooperatives play a crucial role in organizing smallholder farmers to increase production scale and skill worldwide (Cook and Iliopoulos 2000; Ito et al. 2012; Ma et al. 2018; Ma and Zhu 2020). The Chinese government supports a healthy agricultural cooperatives system to provide agricultural extension services and marketing services. For example, China has issued the Law of Farmers' Professional Cooperatives in 2007 and adopted a series of supporting measures to promote the sustainable development of agricultural cooperatives. Among the series of agricultural and environmental related policies and regulations from 2015 to 2020, the Chinese government encouraged and emphasized to promote sustainable agriculture with appropriate use of CFPs through the agricultural cooperative business system. Because the average farm size is less than 0.4 hectares in China, and the majority incomes of smallholder farms are from off-farm work, they lack incentives to join agricultural cooperatives. In response, China has begun to nurture larger-scale and more professional family farms and implemented the "family farm nurturing program" to provide a strong foundation for modern agriculture development since 2018.

Most Chinese agricultural cooperatives have multi-purposes and play three core functions: marketing products, purchasing supplies, and providing services ( $\mathrm{Su}$ and Cook 2020). Providing services and marketing products are equally crucial for agricultural cooperatives and their farmer members. Many marketing cooperatives contract with supermarkets to sell their members' products under the supply chain model of 
“farmers plus cooperatives plus supermarkets" (Chen et al. 2013; Gong et al. 2019). Under this marketing channel, agricultural cooperatives established strict quality standards, including residual levels of fertilizers and pesticides, to meet their buyers' quality demand. Many agricultural cooperatives provide comprehensive services such as input purchase, production training, technique consultation, and field services to help farmer members follow those required standards. Therefore, these agricultural cooperatives play critical roles in controlling the use of CFPs to ensure agricultural products' safety.

Some studies have shown significant positive impacts of cooperative membership on the adoption of agricultural technologies in China (Chen et al. 2013; Liu et al. 2019; Ma et al. 2018; Ma and Abdulai 2019; Zhou et al. 2016; Zhou and Jin 2009). For example, Ma et al. (2018) showed that agricultural cooperative members are more likely to adopt organic fertilizer and farmyard manure in China's apple production. Agricultural cooperatives supply inputs and provide embedded support and training services to make their farmer members technically more efficient. The training effects worked through the following mechanisms. First, good farming practices increase the application efficacy of CFPs and restrict highly toxic pesticides (Zhou and Jin 2009). The second was that farmers substituted chemical fertilizers with organic fertilizers. The other was soil management and integrated pest management (IPM), which reduces the amount needed for CFPs (Ma et al. 2018; Ma and Abdulai 2019). Besides, effective communication between agricultural cooperative and members, trust in the agricultural cooperatives' management team, and the collective organization objectives all are critical for the farmers to practice good agricultural practices (GAP) and follow the CFPs use standards of the agricultural cooperative (Liu et al. 2019; Zhou et al. 2016; Zhou and Jin 2009). Nevertheless, the studies mentioned above mainly focused on smallholder fruit and vegetable farmers, with little attention paid to grain and larger-scale producers. To the best of our knowledge, no previous studies have considered the service-oriented characteristics of Chinese agricultural cooperatives.

This study fills the gaps and contributes to the literature by investigating the impacts of cooperative memberships on reducing the overuse of CFPs for large-scale specialized family farms. We use data of 2012 family farms collected by the Ministry of Agriculture and Rural Affairs of China. ${ }^{1}$ As a further contribution, we employ various approaches, including instrumental variable based two-stage residual inclusion (2SRI) approach, endogenous switching probit model, and endogenous switching regression model, to address the endogeneity issues of the cooperative membership variable. These approaches have significant advantages over other common regression techniques such as ordinary least-square (OLS), probit methods, or propensity score

\footnotetext{
${ }^{1}$ It was named Ministry of Agriculture before 2018.
} 
matching (PSM) approach. In particular, the 2SRI approach can also help obtain more accurate asymptotically correct standard errors (ACSE) for testing $t$-statistics.

The remainder of the paper is structured as follows. Section 2 presents the analytical framework and hypotheses. Section 3 discusses the methods and data sources, and the empirical results and discussions follow this in Section 4. The final section concludes and proposals policy implications.

\section{Analytical framework and hypotheses}

Agricultural cooperatives in China provide multiple functions to their members. Two important ones are to give imitation and guidance of conducting the normative and specialized production (Ma et al. 2018; Zhou et al. 2018) and to promote the coordination between "small production" of single farms and socialized "big markets" (Agbo et al. 2015; Kontogeorgos et al. 2018; Liu et al. 2019). The overuse of CFPs causes severe food quality and safety problems in China and makes consumers lack Chinese food confidence. Under this circumstance, agricultural cooperatives are motivated to guide their farmer members to eliminate the use of highly toxic pesticides and avoid the overuse of agricultural chemicals to ensure food safety and quality. Two critical agricultural cooperative functions, including production services and marketing, help reduce the overuse of CFPs.

\subsection{Production perspective}

1) Mimetic effect. The social learning theory of Bandura and Walters (1977) states that people tend to observe and imitate the behaviors of their peers in a particular circumstance. Gathering information from peers or observing neighboring farms' production behaviors is the primary way for farmers to obtain information and new agricultural technologies (Chavas and Nauges 2020; Grace 2018; Takahashi et al. 2020). After participation in agricultural cooperatives, farmers form a social community and formal network relation with trusted weak ties, which could strengthen the diffusion and communication of new skills and useful knowledge (Fisher et al. 2018; Leta et al. 2018) and thereby promote the completion of imitation process (Oehme and Bort 2015). Observing and imitating agricultural cooperatives peers and technical experts regarding proper practices can help smallholder farmers reduce the misuse or overuse of CFPs. Zhou and Jin (2009) examined the usage of highly toxic pesticides of 507 produce farmers. They found the farmers who imitated their peers' good practice significantly more likely eliminated the misuse of pesticides than those who did not.

2) Normative effect. It is well acknowledged that norms influence groups and individuals' behaviors greatly. Reed and Hickey (2016) found that formal vertical linkage is the predominant channel of innovation 
spread in agricultural cooperatives. In 2017, the Chinese State Council approved the amendment to the "Regulation on the Administration of Pesticides" and restated its previous regulation to require the cooperatives to record the information of all agricultural chemicals applied accurately. Therefore, many agricultural cooperatives have established formal standards for their members' chemical inputs, especially pesticide use (Zhou et al. 2019). Ito et al. (2012) revealed that a watermelon cooperative in Nanjing, Jiangsu province, established a detailed chemical application protocol and paid $20 \%$ premiums to the producer members who followed the protocol.

3) Specialized effect. Compared with individual farms, agricultural cooperatives can obtain economies of scale by pooling the resources and improving agricultural production specialization (Yang and Liu 2012). Chinese agricultural cooperatives provide input purchase, professional production services from planting to harvest, and marketing. Producers adopted good production practices and minimized the overuse of CFPs with the agricultural cooperative service team's help. Li et al. (2014) pointed out that pesticide spraying conducted by specialized agricultural cooperatives contributed to ecological environment protection. In China's Heilongjiang province, 1,481 agricultural cooperatives supply professional fertilizer application using advanced application machinery and precision farming technology. Consequently, the consumption of fertilizers in Heilongjiang province was reduced by $10 \%$ in the leading crops, such as soybean, corn, and rice. ${ }^{2}$

\subsection{Marketing perspective}

High chemical residues create food safety concerns for Chinese agri-products and prevent Chinese farmers from benefiting from international markets (Alita et al. 2020; Liu and Guo 2019; Lu et al. 2015). Improving food safety of agricultural products is an essential task for agricultural cooperatives required by the Chinese government.

Agricultural marketing cooperatives aggregate and market farm products collectively. They have the incentives to meet the market demands of high-quality, safe agricultural food products. Many agricultural cooperatives have signed sales contracts with supermarkets or food manufacturers with specific quality standards under the government's support. Consequently, these agricultural cooperatives set up strict quality standards and require their farmer members to follow them. Additionally, agricultural cooperatives employees supervise the production and monitor their members' production behaviors to ensure their products meet the food safety standards by appropriate use of CFPs (Chen et al. 2013; Giagnocavo et al. 2017; Zhou et al. 2018).

\footnotetext{
${ }^{2}$ Source: http://hlj.people.com.cn/n2/2018/1211/c220024-32394255.html
} 
Chen et al. (2013) investigated the marketing cooperatives selling to 24 supermarkets in China's Beijing and found that these cooperatives hired professional technicians to teach farmer members to use the best pesticide practices. These agricultural cooperatives also conducted pesticide residue tests and heavy metal tests for all products they purchased from their members to ensure quality and safety.

High-quality products ensure the cooperatives to achieve high profits. Some agricultural cooperatives have gradually created their agri-products brands and internalized more external profits (Grashuis 2018; Liu et al. 2019; Sexton and Xia 2018; Zhang et al. 2020). According to the cooperatives' requirements, joining agricultural cooperatives and reducing the consumption of CFPs create more profits for cooperative members (Ito et al. 2012; Liu et al. 2019; Ma and Abdulai 2019). Hence, cooperative members have the incentives to reduce the overuse of agricultural chemicals, especially pesticides, to satisfy the cooperatives' quality standards. Ma and Abdulai (2019) studied 481 apple producers in China's Gansu, Shanxi, and Shandong provinces. They concluded these producers were willing to adopt IPM technology and follow the production protocol established by their cooperatives to reduce chemical pesticide use and get higher net returns.

Based on the discussions above, this study attempts to test the two hypotheses illustrated below:

H1: Good production practices reduce the use of chemical fertilizers and pesticides in agricultural cooperatives in rural China.

H2: Marketing related activities reduce the use of chemical fertilizers and pesticides in agricultural cooperatives in rural China.

\section{Methods and data sources}

\subsection{Econometric model}

Our first objective is to identify the determinants of farmers' participation in an agricultural cooperative. Following Ma and Abdulai (2019) and Mojo et al. (2017), the random utility framework is used to analyze farmers' decision to join an agricultural cooperative. We assume that a rational farmer $i$ will join an agricultural cooperative when the utility of being a member $U_{i}^{m}$ is larger than the utility $U_{i}^{n}$ of not being a member. However, the actual utility levels of a farmer are not observable. But the utility gain, which is defined as $C_{i}^{*}=U_{i}^{m}-U_{i}^{n}$, can be expressed as a function of a vector of observable explanatory variables $Z_{i}$ in the following latent variable model:

$$
C_{i}^{*}=\beta Z_{i}+\varepsilon_{i} \text {, where } C_{i}=1 \text { if } C_{i}^{*}>0 \text { and } C_{i}=0 \text { if } C_{i}^{*}<0
$$

where $C_{i}^{*}$ refers to the probability that a farmer chooses to join an agricultural cooperative, which is determined 

by an observed variable $C_{i}$. In particular, $C_{i}=1$ if a farmer has obtained cooperative membership, and $C_{i}=0$ otherwise. $Z_{i}$ is a vector of factors affecting farmers' decisions to participate in an agricultural cooperative; $\beta$ is the parameters to be estimated, and $\varepsilon_{i}$ is the disturbance term assumed to be normally distributed with zero means.

The probability of a farmer joining an agricultural cooperative is given as follows:

$$
\operatorname{Pr}\left(C_{i}=1\right)=\operatorname{Pr}\left(\varepsilon_{i}>-\beta Z_{i}\right)=1-F\left(-\beta Z_{i}\right)
$$

where $F$ is the cumulative distribution function for $\varepsilon_{i}$.

To link the agricultural cooperative membership with the usage of CFPs, we assume that the usage of CFPs is a linear function of a vector of covariates $X_{i}$ and the dichotomous membership variable $C_{i}$, expressed as follow:

$$
Y_{i}=\alpha X_{i}+\gamma C_{i}+\mu_{i}
$$

where $Y_{i}$ represents a vector of outcome variables of farmer $i$ such as chemical fertilizer reduction, pesticide reduction, and application efficacy of CFPs, defined as the net return per yuan ${ }^{3}$ cost of CFPs. $\alpha$ and $\gamma$ are parameters to be estimated, $\mu_{i}$ is the disturbance term.

In Equation (3), the agricultural cooperatives membership variable $C_{i}$ is potentially endogenous because farmers' decisions to be cooperative members and non-members are affected by observed factors (e.g., age and education) and unobserved factors (e.g., farmers' innate abilities and motivations). Hence, the disturbance term $\varepsilon_{i}$ in Equation (1) and disturbance term $\mu_{i}$ in Equation (3) may be correlated. If the correlation coefficient does not equal zero, i.e., $\operatorname{corr}\left(\varepsilon_{i}, \mu_{i}\right) \neq 0$, selection bias occurs. Standard regression techniques, such as ordinary least-square (OLS) and probit models, fail to account for such selection bias and tend to produce inconsistent estimation results. The propensity score matching (PSM) method addresses the selection bias (Chagwiza et al. 2016; Michalek et al. 2018), but it does not account for the unobservable selection bias issue (Ma and Abdulai 2016). In comparison, the two-stage residual inclusion (2SRI) approach addresses the selection biases arising from both observed and unobserved factors (Terza 2016; Ying et al. 2019). Besides, the 2SRI method can directly investigate the influence of unobservable factors and obtain asymptotically correct standard errors (ACSE) for testing $t$-statistics. This study employs the 2SRI approach to conduct empirical analysis.

In the 2SRI method, the residual term obtained from equation (1) estimation is included in Equation (3) as an additional explanatory variable. Hence, Equation (3) is reformulated as:

$$
Y_{i}=\alpha X_{i}+\gamma C_{i}+\varphi R_{i}+\mu_{i}
$$

\footnotetext{
3 The yuan is the unit of currency in China. In March 2021, one yuan is about US \$0.154.
} 
where $R_{i}$ represents the residual term estimated from Equation (1).

For robustness check and estimating the average treatment effect on the treated (ATT), both the endogenous switching probit (ESP) model and the endogenous switching regression (ESR) model are also estimated. Specifically, in consideration of the nature of the dependent variables, we use the ESP model to evaluate the impact of agricultural cooperative membership on fertilizer reduction and pesticide reduction and employ the ESR model to assess the impact of cooperative membership on CFPs use efficacy (Ma and Zhu 2020).

To identify 2SRI, ESP, and ESR models and improve parametric estimations, $Z_{i}$ in Equation (1) should contain $X_{i}$ plus at least one instrumental variable (IV) that affects the decision of joining agricultural cooperative, but does not directly affect the usage of CFPs (Terza 2016). Following Ma and Abdulai (2016), the regression took the proportion of other family farms' participation in agricultural cooperatives in the studied county as an IV (IV1).

\subsection{Data source and variable description}

The data used for empirical analysis are obtained from a survey by the Ministry of Agriculture and Rural Affairs of China carried from March to April 2016. The survey collects information on household demographic characteristics, production practices, land market participation, application of agricultural chemicals, and agricultural cooperatives' services. After data cleaning by removing samples with missing information, 2012 valid observations were finally used for this study. Because of the lack of net return data due to the new establishment of some family farms or other reasons, some observations were excluded when analyzing the net return per yuan of CFPs.

Table 1 presents the descriptive statistics of the selected variables. It shows that $27.4 \%$ of the family farm heads believed that they applied fewer chemical fertilizers than their neighboring farmers, and $31.0 \%$ having the same perception for pesticides. On average, every yuan input of CFPs brought a net return of 2.23 yuan. Also, $33.9 \%$ of the family farms had participated in agricultural cooperatives, and 335 of them cultivated wheat, rice, and maize as their primary plants. Among these 335 major grain producers, $81.8 \%$ had received technology training service or machinery use service, and $49.0 \%$ had received cooperatives' sales services.

Concerning the characteristics of farm heads, on average, their age was 52.7 years, education was 9.57 years, and large scale farm management experience was 6.13 years, which indicate that they were not well educated and experienced in farm management. The average farm size is 28.79 hectares, and the average price for the rented farmland is 7590.51 yuan/hectare. About $22.4 \%$ of farms had received a rental subsidy from the 
government. The family labors accounted for $75.2 \%$ of the total farm labor force, $61.8 \%$ of the farms cultivated wheat, rice, and maize as their primary plants, and $59.4 \%$ of the farms tested the soil to formulate fertilization. Nevertheless, only $14.8 \%$ of the farms had received quality certification for their agri-products.

\section{Empirical results and discussions}

Before formally discussing the empirical results, we have conducted a variance inflation factor (VIF) test to check the multi-collinearity issues of the variables. The VIF values of explanatory variables in Equation (1) and Equation (4) were less than 1.40 and 2.46, and the condition numbers of those variables were 25.97 and 26.81, respectively. The findings indicate that there were no multi-collinearity issues in our estimated models. The significance of residual terms in columns 3-5 of Table 2 suggested that the unobservable factors simultaneously influenced the decision of agricultural cooperative membership and the usage of CFPs. Thus, the 2SRI model was appropriate and had strong explanatory power.

\subsection{Impact of cooperative membership}

Table 2 reports the regression results of Equation (1) and Equation (4), which are estimated simultaneously with the 2SRI approach for the impacts of agricultural cooperatives on the usage of CFPs. After controlling the endogeneity, the results showed that joining agricultural cooperatives improved the probability of reducing fertilizers and pesticides by $17.4 \%$ and $17.9 \%$, respectively, and increased the net return per yuan cost of CFPs by 0.59 yuan. The above results were all significant at the $10 \%$ level. Yuan et al. (2020) found that Internet use helps reduce fertilizer use in China, while Zhao et al. (2020) showed that Internet use helps reduce pesticide use among vegetable farmers in China. This study provides new evidence that agricultural cooperatives can be an efficient institutional arrangement that reduces both pesticide and fertilizer use in China.

The estimates of Equation (1) by 2SRI approach revealed that education level and farming experience of the farm head, fertilizing based on soil testing, and agri-products quality certification all had positive impacts on farmers' decision to join an agricultural cooperative, whilst the farm size and the proportion of family labor force had a negative effect. These findings are largely consistent with the existing literature on agricultural cooperatives (e.g., Jitmun et al. 2020; Liu et al. 2019; Ma and Abdulai 2019; Manda et al. 2020; Zhang et al. 2020). All of the above variables were statistically significant. The IV1 was positively and statistically significant, indicating that the possibility of a family farm joining an agricultural cooperative was positively associated with the proportion of other family farms participating in cooperatives in the same county. 
4.2. Average treatment effect on the treated (ATT)

The regression results of the ESP and ESR models are presented in Table 3. For the sake of brevity, we only present and discuss the ATT results. The results presented in Table 3 showed that the agricultural cooperative members had a significantly higher probability of reducing the usage of fertilizers and pesticides than the non-member farmers and higher application efficacy of CFPs. The estimated ATT results in Table 3 were positively and statistically significant, which confirmed that agricultural cooperatives could help farmer members reduce the overuse of CFPs and improve the utilization efficacy of the agricultural chemicals. Specifically, after joining an agricultural cooperative, the possibility to reduce the usage of fertilizers and pesticides increased by $30.1 \%$ and $35.9 \%$, respectively, and the net return per yuan of CFPs increased by 7.49 yuan. In conclusion, agricultural cooperatives had a stable and reliable influence on reducing the consumption of CFPs and increasing the application efficacy of CFPs.

\subsection{Mechanism analysis}

We have demonstrated that agricultural cooperatives effectively help their members reduce the usage of CFPs. To further explore how they did it, we focused our analysis exclusively on the grain producers because the grain and other crops were different in production, marketing, and application of CFPs. Very little literature studied the grain producers. In total, 335 major grain producers had used the services (including production services and marketing services) provided by agricultural cooperatives. Since the choice to use the agricultural cooperative services was an endogenous variable, we chose "Demonstration farm" as an IV (IV2) for this analysis. Demonstration farms were exemplary family farms with exceptional financial performance, farming practice, or many other aspects, awarded by Chinese governments at both regional and national levels. Because the awards reflected the relationship between the recipient farms and governments, and the government greatly influenced the development of agricultural cooperatives in China, demonstration farms are more likely to join an agricultural cooperative than their peers due to their close ties with the governments. Moreover, the demonstration farms also can affect other farmers' choices to join an agricultural cooperative and use its services, but not the usage of CFPs. Thus, the demonstration farm met the requirement of a valid IV. The distance to the markets may affect farmers' marketing decisions but not their usage of CFPs. Following Hall and Jones (1999) and Cawley et al. (2018), we used the distance from the farm to the city Hall (IV3) and farm to the provincial capital (IV4) as the IVs of choice of selling to agricultural cooperatives. According to whether the farms used the production services or marketing services provided by agricultural cooperatives, we estimated the impact of cooperative membership on the usage of CFPs by the 2SRI approach. The results are shown in 
Table 4 and Table 5.

The estimated coefficients in columns 3, 4, and 5 of Table 4 indicated that after controlling for other variables, using the production services provided by agricultural cooperatives increased the probability of reducing the consumptions of fertilizers and pesticides by $69.3 \%$ and $47.6 \%$, respectively, and increased the net return per yuan cost of CFPs by 0.58 yuan. Therefore, the hypothesis of H1 has been verified. Besides, compared with the coefficients of membership in Table 2, which did not differentiate the farms using the production services from those not, cooperative production services had a prominently positive effect on reducing the consumption of CFPs.

The marketing services' coefficient in column 4 of Table 5 was significant at the $1 \%$ level, which indicated that using cooperative marketing services decreased the application of pesticides significantly. The hypothesis of H2 was supported. Nevertheless, the marketing services had no significant impacts on the consumption of chemical fertilizers and the net return per yuan CFPs. One possible reason was that pesticide residues were easy to test and monitor, but the overuse of chemical fertilizers was harder to test in final agricultural food products.

In conclusion, agricultural cooperatives made their farmer members lower the usage of CFPs by providing services. Production services had reduced the usage of CFPs and increased the application efficacy of CFPs, while marketing services had significantly decreased pesticide usage.

\section{Conclusions and policy implications}

Farmers' production practices influence agricultural non-point source pollution and the safety and quality of agricultural food products. Public demand for environmental sustainability and safe and higher- quality agricultural food products is increasing. Excessive applications of CFPs created ecologically, and food safety issues have made Chinese consumers distrust domestic producers and prevented Chinese farmers from participating in international markets. This study provided evidence for the roles of agricultural cooperatives in improving the environment and food safety through production services and marketing services to their farmer members. By employing the 2SRI approach and the ATT estimators based on the ESP and ESR models, we quantified the impacts of the agricultural cooperative membership on the consumption of CFPs. We analyzed the mechanisms using the family farm data from the Ministry of Agriculture and Rural Affairs of China.

Our empirical results showed that agricultural cooperatives increase the possibilities of reducing fertilizers and pesticides' consumption. According to ATT estimation results, the cooperative members' net return per yuan CFPs increased by 7.49 yuan. Agricultural cooperative production services reduced the usage of fertilizers 
and pesticides, while cooperatives marketing services only significantly lowered the use of pesticides.

The conclusions of this study have provided the policy implications for China's agricultural green development from three aspects. Firstly, since agricultural cooperatives can play essential roles in protecting the agroecological environment, improving the quality and safety of agricultural food products, disseminating modern agricultural technology, and promoting agricultural production mode transformation, it is necessary to provide policy supports to promote these relative roles of agricultural cooperatives. Secondly, it is vital to offer agricultural production technology and pesticide residues test to agricultural cooperatives, support cooperatives to provide agricultural production services and marketing services for family farms and strengthen the role of cooperatives in managing the process of agricultural production and supervising the quality of agri-products. Finally, it is essential to encourage more family farms to join agricultural cooperatives, especially larger-scale and skilled family farms and make them the backbone of the agricultural cooperatives; it is also critical to assist cooperatives to guide family farms to effectively use agricultural inputs especially CFPs, and achieve the coordinated development between agricultural cooperatives and family farms.

The study has confirmed using cooperative marketing services helped farmers reduce the consumption of pesticides but had little influence on the consumption of chemical fertilizers. And it is unclear whether their usage of CFPs is proper. Appropriate production and use of the CPFs are essential to protect human health and the environment. This job needs society's efforts, including individual producers, agricultural cooperatives, governments, and the public. The government should ensure that the agricultural cooperatives can provide farmer members with technical training to use CFPs properly and make the agricultural cooperatives aware of the importance of monitoring the agricultural chemicals application and quality control. It is also necessary to educate the farmers to access the market information through the internet to understand consumer demand for food safety and quality to earn a premium profit.

\section{References}

Agbo M, Rousselière D, Salanié J (2015) Agricultural marketing cooperatives with direct selling: a cooperativenon-cooperative game. J Econ Behav Organ 109: 56-71. https://doi.org/10.2139/ssrn.2556117

Alita L, Dries L, Oosterveer P (2020) Chemical vegetable safety in China: "supermarketisation" and its limits. Brit Food J 122(11): 3433-3449. https://doi.org/10.1108/bfj-08-2019-0627

Bandura A, Walters RH (1977) Social learning theory. Prentice-hall, Englewood Cliffs, New Jersey

Cawley A, O'Donoghue C, Heanue K, Hilliard R, Sheehan M (2018) The impact of extension services on farm-level income: an instrumental variable approach to combat endogeneity concerns. Appl Econ Perspect P 40(4): 585-612. https://doi.org/10.1093/aepp/ppx062

Chagwiza C, Muradian R, Ruben R (2016) Cooperative membership and dairy performance among smallholders in Ethiopia. Food Policy 59: 165-173. https://doi.org/10.1016/j.foodpol.2016.01.008

Chavas JP, Nauges C (2020) Uncertainty, learning, and technology adoption in agriculture. Appl Econ Perspect P 42(1): 42-53. https://doi.org/10.1002/aepp.13003 
Chen J, Shen L, Zhong X (2013) Quality control research and analysis of fruit and vegetable in Beijing supermarket. $\quad$ Advanced $\quad$ Materials $\quad$ Research $1373-1376$. https://doi.org/10.4028/www.scientific.net/amr.781-784.1373

Cook ML, Iliopoulos C (2000) Ill-defined property rights in collective action: the case of US agricultural cooperatives. In: Menard C (ed) Institutions, contracts and organizations. E Elger Pub, London, pp 335-348. https://doi.org/10.4337/9781781952764.00036

Fisher M, Holden ST, Thierfelder C, Katengeza SP (2018) Awareness and adoption of conservation agriculture in Malawi: what difference can farmer-to-farmer extension make? Int J Agr Sustain 16: 310-325. https://doi.org/10.1080/14735903.2018.1472411

Giagnocavo C, Bienvenido F, Li M, Zhao YR, Sanchez-Molina JA, Yang XT (2017) Agricultural cooperatives and the role of organisational models in new intelligent traceability systems and big data analysis. Int J Agr Biol Eng 10(5): 115-125. https://doi.org/10.25165/j.ijabe.20171005.3089

Gong TC, Battese GE, Villano RA (2019) Family farms plus cooperatives in China: technical efficiency in crop production. J Asian Econ 64: 101129. https://doi.org/10.1016/j.asieco.2019.07.002

Grace WK (2018) Use of biochar for increased crop yields and reduced climate change impacts from agricultural ecosystems: Chinese farmers perception and adoption strategy. Afr J Agr Res 13(21): 1063-1070. https://doi.org/10.5897/ajar2018.13037

Grashuis J (2018) The impact of brand equity on the financial performance of marketing cooperatives. Agribusiness 35(2): 234-248. https://doi.org/10.1002/agr.21574

Hall RE, Jones CI (1999) Why do some countries produce so much more output per worker than others? The Quarterly Journal of Economics 114(1): 83-116. https://doi.org/10.1162/003355399555954

Huang QQ, Yu Y, Wan YN, Wang Q, Luo Z, Qiao YH, Su DC, Li HF (2018) Effects of continuous fertilization on bioavailability and fractionation of cadmium in soil and its uptake by rice (Oryza sativa L.). J Environ Manage 215: 13-21. https://doi.org/10.1016/j.jenvman.2018.03.036

Ito J, Bao ZS, Su Q (2012) Distributional effects of agricultural cooperatives in China: exclusion of smallholders and potential gains on participation. Food Policy 37(6): 700-709. https://doi.org/10.1016/j.foodpol.2012.07.009

Jitmun T, Kuwornu JKM, Datta A, Kumar Anal A (2020) Factors influencing membership of dairy cooperatives: evidence from dairy farmers in Thailand. J Co-op Organ Manag 8(1): 100109. https://doi.org/10.1016/j.jcom.2020.100109

Kontogeorgos A, Sergaki P, Kosma A, Semou V (2018) Organizational models for agricultural cooperatives: empirical evidence for their performance. J Knowl Econ 9(4): 1123-1137. https://doi.org/10.1007/s13132-016-0402-8

Kuang FY, Chen MQ, Li ZP, Peng XX, Liu J, Liu YY (2018) Analysis on the difference between farmers' ecological environment cognition and protective behavior basedon using pesticide and chemical fertilizer. Research of Soil And Water Conservation 25(1): 321-326 (in Chinese)

Li HZ, Zeng EY, You J (2014) Mitigating pesticide pollution in China requires law enforcement, farmer training, and technological innovation. Environ Toxicol Chem 33(5): 963-971. https://doi.org/10.1002/etc.2549

Li S, Lei YD, Zhang YY, Liu JG, Shi XY, Jia H, Wang C, Chen F, Chu QQ (2019) Rational trade-offs between yield increase and fertilizer inputs are essential for sustainable intensification: a case study in wheat-maize cropping systems in China. Sci Total Environ 679: 328-336. https://doi.org/10.1016/j.scitotenv.2019.05.085

Liu PJ, Guo YZ (2019) Current situation of pesticide residues and their impact on exports in China. IOP C Ser Earth Env 227(5): 052027. https://doi.org/10.1088/1755-1315/227/5/052027

Liu YY, Ma WL, Renwick A, Fu XH (2019) The role of agricultural cooperatives in serving as a marketing channel: evidence from low-income regions of Sichuan province in China. Int Food Agribus Man 22(2): 265-282. https://doi.org/10.22434/ifamr2018.0058

Lu YL, Song S, Wang RS, Liu ZY, Meng J, Sweetman AJ, Jenkins A, Ferrier RC, Li H, Luo W, Wang TY (2015) Impacts of soil and water pollution on food safety and health risks in China. Environ Int 77: 5-15. https://doi.org/10.1016/j.envint.2014.12.010

Ma WL, Abdulai A (2016) Does cooperative membership improve household welfare? Evidence from apple farmers in China. Food Policy 58: 94-102. https://doi.org/10.1016/j.foodpol.2015.12.002

Ma WL, Abdulai A (2019) IPM adoption, cooperative membership and farm economic performance. China Agr Econ Rev 11(2): 218-236. https://doi.org/10.1108/caer-12-2017-0251

Ma WL, Abdulai A, Ma CB (2018) The effects of off-farm work on fertilizer and pesticide expenditures in China. Rev Dev Econ 22(2): 573-591. https://doi.org/10.1111/rode.12354

Ma WL, Renwick A, Yuan P, Ratna N (2018) Agricultural cooperative membership and technical efficiency of apple farmers in China: an analysis accounting for selectivity bias. Food Policy 81: 122-132. https://doi.org/10.1016/j.foodpol.2018.10.009

Ma WL, Zhu ZK (2020) A note: reducing cropland abandonment in China-do agricultural cooperatives play a role? J Agr Econ 71(3): 929-935. https://doi.org/10.1111/1477-9552.12375 
Manda J, Khonje MG, Alene AD, Tufa AH, Abdoulaye T, Mutenje M, Setimela P, Manyong V (2020) Does cooperative membership increase and accelerate agricultural technology adoption? Empirical evidence from Zambia. Technol Forecast Soc 158: 120160. https://doi.org/10.1016/j.techfore.2020.120160

Michalek J, Ciaian P, Pokrivcak J (2018) The impact of producer organizations on farm performance: the case study of large farms from Slovakia. Food Policy 75: 80-92. https://doi.org/10.1016/j.foodpol.2017.12.009

Mojo D, Fischer C, Degefa T (2017) The determinants and economic impacts of membership in coffee farmer cooperatives: recent evidence from rural Ethiopia. J RURAL STUD 50: 84-94. https://doi.org/10.1016/j.jrurstud.2016.12.010

Oehme M, Bort S (2015) SME internationalization modes in the German biotechnology industry: the influence of imitation, network position, and international experience. J Int Bus Stud 46(6): 629-655. https://doi.org/10.1057/jibs.2015.8

Pan D, He MM, Kong FB (2020) Risk attitude, risk perception, and farmers' pesticide application behavior in China: a moderation and mediation model. J Clean Prod 276: 124241. https://doi.org/10.1016/j.jclepro.2020.124241

Reed G, Hickey GM (2016) Contrasting innovation networks in smallholder agricultural producer cooperatives: insights from the Niayes Region of Senegal. J Co-op Organ Manag 4(2): 97-107. https://doi.org/10.1016/j.jcom.2016.09.001

Sexton RJ, Xia T (2018) Increasing Concentration in the agricultural supply chain: implications for market power and sector performance. Annu Rev Resour Econ 10: 229-251. https://doi.org/10.1146/annurev-resource-100517-023312

Su Y, Cook ML (2020) Advances in agricultural cooperative research since 2007: a review of Chinese agricultural economics literature. Ann Public Coop Econ 94(4): 519-543. https://doi.org/10.1111/apce.12273

Takahashi K, Muraoka R, Otsuka K (2020) Technology adoption, impact, and extension in developing countries' agriculture: a review of the recent literature. Agr Econ 51(1): 31-45. https://doi.org/10.1111/agec.12539

Terza JV (2016) Simpler standard errors for two-stage optimization estimators. The Stata Journal 16(2): 368-385. https://doi.org/10.1177/1536867x1601600206

Wu YY, Xi XC, Tang X, Luo DM, Gu BJ, Lam SK, Vitousek PM, Chen DL (2018) Policy distortions, farm size, and the overuse of agricultural chemicals in China. P Natl Acad Sci USA 115(27): 7010-7015. https://doi.org/10.1073/pnas.1806645115

Yang D, Liu ZM (2012) Does farmer economic organization and agricultural specialization improve rural income? Evidence from China. Econ Model 29(3): 990-993. https://doi.org/10.1016/j.econmod.2012.02.007

Ying A, Xu RH, Murphy J (2019) Two-stage residual inclusion for survival data and competing risks-an instrumental variable approach with application to SEER-Medicare linked data. Stat Med 38(10): 1775-1801. https://doi.org/10.1002/sim.8071

Yuan F, Tang K, Shi QH (2021) Does Internet use reduce chemical fertilizer use? Evidence from rural households in China. Environ Sci Pollut R 28(5): 6005-6017. https://doi.org/10.1007/s11356-020-10944-4

Zhang SM, Sun ZL, Ma WL, Valentinov V (2020) The effect of cooperative membership on agricultural technology adoption in Sichuan, China. China Econ Rev 62: 101334. https://doi.org/10.1016/j.chieco.2019.101334

Zhao QQ, Pan YH, Xia XL (2021) Internet can do help in the reduction of pesticide use by farmers: evidence from rural China. Environ Sci Pollut R 28(2): 2063-2073. https://doi.org/10.1007/s11356-020-10576-8

Zheng S, Wang ZG, Wachenheim CJ (2019) Technology adoption among farmers in Jilin Province, China. China Agr Econ Rev 11(1): 206-216. https://doi.org/10.1108/caer-11-2017-0216

Zhou JH, Jin SS (2009) Safety of vegetables and the use of pesticides by farmers in China: evidence from Zhejiang province. Food Control 20(11): 1043-1048. https://doi.org/10.1016/j.foodcont.2009.01.002

Zhou JH, Liu Q, Liang Q (2018) Cooperative membership, social capital, and chemical input use: evidence from China. Land Use Policy 70: 394-401. https://doi.org/10.1016/j.landusepol.2017.11.001

Zhou JH, Yan Z, Li K (2016) Understanding farmer cooperatives' self-inspection behavior to guarantee agri-product safety in China. Food Control 59: 320-327. https://doi.org/10.1016/j.foodcont.2015.05.035

Zhou JH, Yang ZY, Li K, Yu XH (2019) Direct intervention or indirect support? The effects of cooperative control measures on farmers' implementation of quality and safety standards. Food Policy 86: 101728. https://doi.org/10.1016/j.foodpol.2019.05.011 
499 Table 1 Descriptive statistics of variables.

\begin{tabular}{|c|c|c|c|}
\hline Variables & Description & Value & S.D. \\
\hline \multicolumn{4}{|c|}{ Dependent variables } \\
\hline $\begin{array}{l}\text { Fertilizer } \\
\text { reduction }\end{array}$ & $\begin{array}{l}\text { Whether the farm has lowered the usage of chemical fertilizers } \\
\text { per } \mathrm{mu}^{4} \text { than surrounding farms? (Reported by farm head): } 0=\text { no; } \\
1=\text { yes }\end{array}$ & 0.274 & 0.446 \\
\hline $\begin{array}{l}\text { Pesticide } \\
\text { reduction }\end{array}$ & $\begin{array}{l}\text { Whether the farm has lowered the usage of pesticides per mu than } \\
\text { surrounding farms? (Reported by farm head): } 0=\text { no; } 1=\text { yes }\end{array}$ & 0.310 & 0.462 \\
\hline $\begin{array}{l}\text { Net return per } \\
\text { yuan CFPs }\end{array}$ & Net return per yuan cost of CFPs (yuan) & 2.234 & 4.983 \\
\hline \multicolumn{4}{|c|}{ Treatment variables } \\
\hline Membership & Cooperative membership: $0=$ no; $1=$ yes & 0.339 & 0.473 \\
\hline $\begin{array}{l}\text { Production } \\
\text { services }\end{array}$ & $\begin{array}{l}\text { Has the farm used the technology service or machinery service } \\
\text { provided by cooperatives in the last year? (Among the major } \\
\text { grain producer members): } 0=\text { no; } 1=\text { yes }\end{array}$ & 0.818 & 0.386 \\
\hline $\begin{array}{l}\text { Marketing } \\
\text { services }\end{array}$ & $\begin{array}{l}\text { Has the farm used the agri-products sales services provided by the } \\
\text { cooperatives in the last year? (Among the major grain producer } \\
\text { members): } 0=\text { no; } 1=\text { yes }\end{array}$ & 0.490 & 0.501 \\
\hline \multicolumn{4}{|c|}{ Independent variables } \\
\hline Age & Age of farm head (year) & 52.706 & 132.236 \\
\hline Education & $\begin{array}{l}\text { Farm head's education years }(18=\text { master's degree; } 16= \\
\text { bachelor's degree; } 14=\text { college degree; } 11=\text { high } \\
\text { school/professional high school diploma; } 8=\text { middle school } \\
\text { diploma; } 5=\text { elementary school; } 0=\text { illiterate })\end{array}$ & 9.567 & 2.361 \\
\hline Year & Farm head's years of large scale farm management & 6.132 & 4.547 \\
\hline Size & Area of land operated by farms (hectare) & 28.788 & 67.589 \\
\hline Rent & The average rent of farmland (yuan/hectare) & 7590.510 & 4909.808 \\
\hline Subsidy & $\begin{array}{l}\text { Whether the farm has received a rental subsidy from the } \\
\text { government? } 0=\text { no; } 1=\text { yes }\end{array}$ & 0.224 & 0.417 \\
\hline Labor & The proportion of family labors in the total farm labor force & 0.752 & 0.989 \\
\hline Grain & The proportion of the sown area of wheat, corn, and rice in 2015 & 0.618 & 0.428 \\
\hline Soil & $\begin{array}{l}\text { Whether the farm tested soil for formulated fertilization in } 2015 \text { ? } \\
0=\text { no; } 1=\text { yes }\end{array}$ & 0.594 & 0.491 \\
\hline Certification & $\begin{array}{l}\text { Whether the agricultural food products have ever been certificated } \\
\text { "pollution-free agri-products", "green foods", "organic products" }\end{array}$ & 0.148 & 0.355 \\
\hline
\end{tabular}

4 The mu is a common unit of land area in China. One mu is about 0.067 hectare. 
or "geographical indications of agri-products"? $0=$ no; $1=$ yes

Typology The main type of land typology in the farm: $1=$ plain; $2=$ hills; $3=$ mountain land

$1.436 \quad 0.715$

How many seasons do the farmlands plant? (Calculation based on

Cropping the areas of the biggest plot of land) 
Table 2 Impact of cooperative membership on the usage of CFPs: 2SRI model estimations

\begin{tabular}{|c|c|c|c|c|}
\hline & $\begin{array}{l}\text { Cooperative } \\
\text { membership }\end{array}$ & $\begin{array}{l}\text { Fertilizer } \\
\text { reduction }\end{array}$ & $\begin{array}{l}\text { Pesticide } \\
\text { reduction }\end{array}$ & $\begin{array}{c}\text { Net return per } \\
\text { yuan CFPs }\end{array}$ \\
\hline Membership & & $0.174 * *(0.073)$ & $0.179 * *(0.071)$ & $0.586 * *(0.343)$ \\
\hline Age & $0.004(0.028)$ & $0.022(0.029)$ & $0.030(0.031)$ & $0.037(0.054)$ \\
\hline Education & $0.056 *(0.032)$ & $0.097 * * *(0.034)$ & $0.036(0.033)$ & $-0.155^{* * *}(0.084)$ \\
\hline Year & $0.020 * * *(0.007)$ & $0.013 *(0.007)$ & $0.010(0.007)$ & $0.063 *(0.022)$ \\
\hline Size & $-0.411 * * *(0.122)$ & $-0.348^{* * *}(0.132)$ & $-0.388 * * *(0.131)$ & $-0.458 * * *(0.419)$ \\
\hline Rent & $0.091(0.077)$ & $0.311 * * *(0.082)$ & $0.143 *(0.083)$ & $0.038 * * *(0.186)$ \\
\hline Subsidy & $0.155^{* *}(0.066)$ & $0.470 * * *(0.072)$ & $0.370 * * *(0.071)$ & $-0.380 * * *(0.297)$ \\
\hline Labor & $0.485 * * *(0.092)$ & $0.107(0.111)$ & $-0.070(0.112)$ & $0.756(0.440)$ \\
\hline Grain & $-0.059(0.049)$ & $0.148 * * *(0.049)$ & $0.129 * * *(0.049)$ & $-0.316^{* * *}(0.249)$ \\
\hline Soil & $0.092 * * *(0.033)$ & $-0.077 * *(0.035)$ & $-0.013(0.036)$ & $-0.648 * *(0.218)$ \\
\hline Certification & $0.008(0.018)$ & $-0.030 *(0.018)$ & $-0.030 *(0.018)$ & $-0.349 *(0.268)$ \\
\hline Typology & $-0.115(0.085)$ & $-0.280 * * *(0.088)$ & $-0.344 * * *(0.088)$ & $0.942 * * *(0.559)$ \\
\hline Cropping & $-0.060(0.052)$ & $0.215 * * *(0.053)$ & $0.259 * * *(0.055)$ & $-0.448 * * *(0.185)$ \\
\hline Residual & & $0.734 * * *(0.235)$ & $0.991 * * *(0.234)$ & $-0.354 * * *(0.882)$ \\
\hline IV1 & $2.130 * * *(0.160)$ & & & \\
\hline Constant term & $-1.271 * * *(0.250)$ & $-1.066 * * *(0.257)$ & $-1.034 * * *(0.256)$ & $7.410 * * *(3.107)$ \\
\hline $\begin{array}{l}\text { Log-pseudo } \\
\text { likelihood }\end{array}$ & -1084.815 & -1044.589 & -1115.657 & -5755.018 \\
\hline Observations & 2012 & 2012 & 2012 & 1917 \\
\hline
\end{tabular}

502 Note: Asymptotically correct standard errors (ACSE) are in in parentheses.

$503 * * *, * *$, and $*$ represent the $1 \%, 5 \%$, and $10 \%$ significance levels, respectively. To eliminate the dimension, this 504 study has standardized the variables of Age and Education, which applies to all the following analyses. 
Table 3 Results of the robustness check

\begin{tabular}{lcccccc}
\hline & \multicolumn{2}{c}{ ESP model } & & \multicolumn{2}{c}{ ESR model } \\
\cline { 2 - 3 } \cline { 5 - 6 } & ATT & $t$-value & & ATT & $t$-value \\
\hline Fertilizer reduction & $0.301 * * *(0.005)$ & 55.083 & Net & return & per & \\
Pesticide reduction & $0.359 * * *(0.005)$ & 78.286 & yuan CFPs & & & \\
\hline
\end{tabular}

507 Note: Standard errors are in parentheses.

$508 * * *$ represent the $1 \%$ significance level.

509 
510 Table 4 Impacts of using cooperative production services on the usage of CFPs: 2SRI model

511 estimations.

\begin{tabular}{lcccc}
\hline & Production services & Fertilizer & Pesticide & Net return per \\
reduction & reduction & yuan CFPs \\
\hline Production & & $0.476 * * *(0.241)$ & $0.693 * * *(0.244)$ & $0.579 * * *(0.337)$ \\
services & & & & \\
Age & $0.105 * * *(0.039)$ & $0.020(0.075)$ & $0.693 * * *(0.244)$ & $0.203(0.203)$ \\
Education & $0.029(0.088)$ & $0.016(0.163)$ & $0.032(0.069)$ & $0.119(0.140)$ \\
Year & $-0.016(0.015)$ & $0.030(0.028)$ & $-0.013(0.149)$ & $-0.012(0.028)$ \\
Size & $-0.208(0.312)$ & $-0.145(0.550)$ & $0.029(0.027)$ & $-0.173(0.597)$ \\
Rent & $-0.008(0.217)$ & $0.294(0.353)$ & $-0.097(0.510)$ & $0.501(0.341)$ \\
Subsidy & $0.187(0.201)$ & $-0.003(0.380)$ & $-0.036(0.330)$ & $-0.300(0.396)$ \\
Labor & $-0.586 * * *(0.196)$ & $0.962 *(0.514)$ & $-0.120(0.350)$ & $-0.172 *(0.501)$ \\
Grain & $-0.07(0.173)$ & $0.543(0.305)$ & $0.809 *(0.473)$ & $0.120(0.375)$ \\
Soil & $0.057(0.116)$ & $-0.077(0.199)$ & $0.375(0.283)$ & $-0.715(0.191)$ \\
Certification & $0.068(0.075)$ & $-0.135(0.173)$ & $0.027(0.183)$ & $-0.285(0.283)$ \\
Typology & $0.058(0.407)$ & $-1.198(0.674)$ & $-0.187(0.160)$ & $-0.061(0.680)$ \\
Cropping & $-0.078(0.212)$ & $0.649 * * *(0.331)$ & $-0.507(0.621)$ & $-1.281 * * *(0.314)$ \\
Residual & & $6.094 * *(2.430)$ & $0.860 * * *(0.309)$ & $-4.715 * *(2.718)$ \\
IV2 & $0.268 * * *(0.103)$ & & & \\
Constant term & $0.458(0.856)$ & $-5.55 * *(2.256)$ & $-5.424 * *(2.100)$ & $12.559 * *(3.027)$ \\
Log-pseudo & -144.740 & -174.597 & -182.525 & -705.447 \\
likelihood & 335 & 335 & 335 & 330 \\
Observations & & & & \\
\hline
\end{tabular}

512 Note: Asymptotically correct standard errors (ACSE) are in parentheses.

$513 * * *, * *$, and $*$ represent the $1 \%, 5 \%$, and $10 \%$ significance levels, respectively. 
515 Table 5 Impacts of using cooperative marketing services on the usage of CFPs: 2SRI model 516 estimations.

\begin{tabular}{|c|c|c|c|c|}
\hline & $\begin{array}{c}\text { Marketing services } \\
\text { use }\end{array}$ & $\begin{array}{l}\text { Fertilizer } \\
\text { reduction }\end{array}$ & $\begin{array}{l}\text { Pesticide } \\
\text { reduction }\end{array}$ & $\begin{array}{c}\text { Net return per } \\
\text { yuan CFPs }\end{array}$ \\
\hline Marketing services & & $0.170(0.165)$ & $0.464 * * *(0.164)$ & $0.041(0.239)$ \\
\hline Age & $0.171 * *(0.075)$ & $-0.017(0.087)$ & $-0.010(0.081)$ & $0.081(0.184)$ \\
\hline Education & $0.190 * *(0.078)$ & $-0.058(0.142)$ & $-0.099(0.131)$ & $-0.072(0.187)$ \\
\hline Year & $0.014(0.015)$ & $-0.017(0.023)$ & $-0.015(0.022)$ & $-0.005(0.026)$ \\
\hline Size & $-0.310(0.310)$ & $-0.407(0.451)$ & $-0.340(0.434)$ & $0.254(0.556)$ \\
\hline Rent & $-0.212(0.184)$ & $0.335(0.281)$ & $0.024(0.262)$ & $0.748^{* *}(0.332)$ \\
\hline Subsidy & $0.026(0.178)$ & $0.388(0.258)$ & $0.228(0.240)$ & $-0.482(0.355)$ \\
\hline Labor & $-0.592 * * *(0.186)$ & $0.630(0.400)$ & $0.526(0.366)$ & $0.790(0.611)$ \\
\hline Grain & $0.103(0.175)$ & $0.223(0.252)$ & $0.066(0.237)$ & $-0.014(0.444)$ \\
\hline Soil & $0.011(0.099)$ & $0.102(0.140)$ & $0.197(0.134)$ & $-0.787 * * *(0.179)$ \\
\hline Certification & $0.098(0.096)$ & $-0.163(0.127)$ & $-0.216^{*}(0.119)$ & $-0.462(0.313)$ \\
\hline Typology & $-0.138(0.344)$ & $-0.881 *(0.512)$ & $-0.184(0.470)$ & $-0.169(0.619)$ \\
\hline Cropping & $-0.139(0.172)$ & $0.815^{* * *}(0.259)$ & $1.028 * * *(0.243)$ & $-1.240 * * *(0.314)$ \\
\hline Residual & & $2.712 * *(1.331)$ & $2.330 *(1.241)$ & $1.523(2.033)$ \\
\hline IV3 & $-0.004^{* *}(0.002)$ & & & \\
\hline IV4 & $0.001 * *(0.0004)$ & & & \\
\hline Constant term & $-0.351(1.109)$ & $-1.739 *(1.186)$ & $-1.982 *(1.117)$ & $9.831 * * *(2.630)$ \\
\hline $\begin{array}{l}\text { Log-pseudo } \\
\text { likelihood }\end{array}$ & -206.746 & -183.430 & -189.145 & -708.356 \\
\hline Observations & 335 & 335 & 335 & 330 \\
\hline
\end{tabular}

517 Note: Asymptotically correct standard errors (ACSE) are in parentheses.

$518 * * *, * *$, and $*$ represent the $1 \%, 5 \%$, and $10 \%$ significance levels, respectively. 
519 Declarations

520 Ethics approval and consent to participate

521 Not applicable

522

523 Consent for publication

524 Not applicable

525

526 Availability of data and materials

$527 \quad$ Not applicable

528

529 Competing interests

530 The authors declare that they have no competing interests.

531

532

\section{Funding}

533 The authors acknowledge the financial support from the National social science foundation of China (Project ID:

534 19BJY127).

535

536

\section{Authors' contributions}

537 All authors contributed to the study conception and design. Tongshan Liu made substantial contributions to the 538 conception or design of the work. The draft was mainly written by Tongshan Liu. Gang Wu performed the 539 literature search and data analysis. All authors read and approved the final manuscript.

540 